\title{
Guidelines for the marketing of independent schools in South Africa
}

\author{
Authors: \\ Reaan Immelman ${ }^{1}$ \\ Mornay Roberts-Lombard ${ }^{1}$ \\ Affiliations: \\ ${ }^{1}$ Department of Marketing \\ Management, University of \\ Johannesburg, South Africa \\ Correspondence to: \\ Mornay Roberts-Lombard \\ Email: \\ mornayrl@uj.ac.za \\ Postal address: \\ PO Box 524, Auckland Park \\ 2006, South Africa \\ Dates: \\ Received: 03 Dec. 2013 \\ Accepted: 18 July 2014 \\ Published: 27 Feb. 2015 \\ How to cite this article: \\ Immelman, R. \& \\ Roberts-Lombard, M., 2015, \\ 'Guidelines for the marketing \\ of independent schools in \\ South Africa', Acta Commercii \\ 15(1), Art. \#245, 9 pages. \\ http://dx.doi.org/10.4102/ \\ ac.v15i1.245

\section{Copyright:} \\ (C) 2015. The Authors. \\ Licensee: AOSIS \\ OpenJournals. This work is \\ licensed under the Creative \\ Commons Attribution \\ License.
}

Read online:

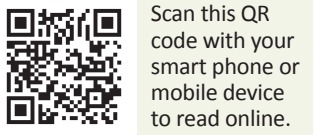

Objective: The primary objective of the study is to recommend marketing guidelines for independent primary schools, with the focus on product and people in the marketing mix. This objective was achieved by identifying choice factors influencing parents' selection of independent primary schools, identifying the most important choice factors and demographic differences regarding the importance parents attached to these factors.

Problem investigated: Some independent schools in South Africa find it difficult to market themselves effectively as a result of a lack of information pertaining to the choice factors identified by parents when selecting independent primary schools. A comprehensive set of choice factors will provide a more accurate picture of the criteria parents perceive as important in independent school selection.

Methodology: The methodological approach followed was exploratory and quantitative in nature. The sample consisted of 669 respondents from 30 independent schools in Gauteng in South Africa. A structured questionnaire, with a five-point Likert scale, was fielded to gather the data. The descriptive and factor analysis approaches were used to analyse the results.

Findings and implications: The main finding is that a total of 29 different choice factors were identified that parents perceive as important when selecting an independent primary school. The most important factor for parents when making a choice is the small size of the classes, followed by the religious ethos of the school as well as qualified and committed educators. This indicates that parents have a comprehensive set of choice factors and implies that a better understanding of these factors by independent schools may assist them to focus their marketing efforts more optimally in order to attract new learners.

Originality and value of the research: Very little research exists with specific reference to independent school marketing in South Africa. The importance of the research study at hand stems from the fact that some parents are dissatisfied with the public schools system, stimulating the demand for independent schools in the country. The increased level of competition amongst independent schools in South Africa therefore necessitates that these schools gain knowledge on the choice factors of parents when selecting such a school. This will assist independent primary schools in the development and design of their individual marketing strategies when recruiting new learners.

\section{Introduction}

Contemporary parents have high expectations of the schools where their children are educated and schools compete amongst each other to attract new learners (Oplatka 2007:218). Prospective parents in South Africa are not forced to enrol their child at the nearest school, but have the choice to enrol learners at the school of their preference (Van Wyk \& Bisschoff 2012:431). The South African Schools Act (No. 84 of 1996) recognises two broad categories of schools, namely public schools and independent schools.

When the Act was passed in 1996, all former state and state-aided schools were deemed to be public schools and all private schools were absorbed into the independent schools category (Federation of Governing Bodies of South African Schools 2013). The number of independent schools in South Africa has more than tripled from 518 in 1994 to 1571 independent schools in 2012 (Roodt 2011:2). This increase in the number of learners attending independent schools could be an indication that parents are losing faith in the public school system (International Finance Corporation 2010). The growth in the independent school industry is driven by the growing middle class in South Africa wanting high-quality education and the fact that the government is not building new schools in affluent areas (Hasenfuss 2011). 
Parents are in general more selective in their choice of school for their children and they do their own research regarding where to enrol their child (Molland 2007:22). Consumers are not passive choosers and are better informed about the choices available to them (Petruzzellis \& Romanazzi 2010:149). Education is regarded as a service and, in the South African context, the service industry represented 70\% of the gross domestic product in 2009 (Boshoff \& Du Plessis 2009:4). Education as a service is however intangible (Cant \& Van Heerden 2010:450), which makes the decision-making about a school for parents difficult. The decision-making process of services consists of the pre-purchase stage, the service encounter stage and the post-encounter stage (Wells \& Foxall 2012:128). This article will focus on the third stage in the pre-purchase stage, namely the evaluation of alternatives. Evaluation criteria are the criteria that consumers decide are acceptable when searching for a solution to their problems and are those features or characteristics that consumers are looking for when buying a specific product or service (Hawkins, Mothersbough \& Mookerjee 2010:649). According to Losike-Sedimo (2011:39), it is important for schools to know what parents and prospective parents want for their children and for schools to learn how best to serve their clients (parents). Very little research exists with specific reference to school marketing in South Africa. This includes research by McAlister (2005:2) where the researcher aimed to identify the importance of marketing in the independent school market in South Africa and to understand management's attitudes towards marketing. The research by Malherbe (2004:82) was to establish whether independent schools in Gauteng have embraced a culture of marketing and to study the effect of such marketing on the image of independent schools. There is limited research in South Africa with regard to the choice factors of parents when selecting independent primary schools. The problem statement is that some independent schools find it difficult to market themselves effectively as a result of a lack of information pertaining to the choice factors identified by parents when selecting an independent school (B.J. Fourie pers. comm., 12 January 2012). In this study, the researcher specifically aims to determine which factors prospective parents consider when choosing independent primary schools in Gauteng. This information will assist independent schools because marketing guidelines will be provided to these schools with the aim to help them to attract more learners.

This article includes a literature review of the marketing of independent schools, the consumer decision-making process, the choice factors of parents selecting independent schools and an explanation of the problem that was investigated. The research objectives, hypotheses and methodology are then discussed. Thereafter, the empirical results are discussed followed by management implications.

\section{Theoretical background}

Competition in the independent school industry is intense because current market forces compel schools to compete with one another (Bisschoff, Du Plessis \& Smith 2004:1).
The ability of independent schools to survive and grow would be enhanced by knowledge of what motivates parents when selecting independent schools in order to assist these schools in better selecting their marketing efforts (McGovern 2012:16). The marketing of independent schools is evident at some independent schools in South Africa. An example is the Independent Schools' Marketing Association (ISMA) which is recognised as an affinity group and stakeholder of the Independent Schools Association of Southern Africa (ISASA) with the objective of promoting marketing efficiency amongst the schools served by each of its members (ISASA 2013). Therefore, the marketing of schools has become an indispensable managerial function; without it a school cannot survive in the current competitive environment in which it operates (Oplatka \& Hemsley-Brown 2004:377).

\section{The marketing of independent schools and the consumer behaviour decision-making process}

School marketing is defined as the means by which a school actively communicates and promotes its purpose, values and products to learners, parents, staff and the wider community (Sferle et al. 2012:765). Literature on school marketing originated in the United States of America and the United Kingdom and major themes covered by research in school marketing include the attitudes of school principals and other stakeholders towards the concept of marketing, the lack of research in school marketing and general literature on how to market a school (Oplatka \& HemsleyBrown 2004:375). According to Soedijati and Pratminingsih (2011:212), the development of a marketing strategy involves the coordination and combination of all elements of the marketing mix. The traditional marketing mix of product, place, price and promotion (also referred to as integrated marketing communication or IMC) needs to be expanded to include three additional Ps, namely people, processes and physical evidence. Within the context of this study, the marketing mix elements can be applied as follows: product could, for example, refer to the curriculum followed by the school, price could include school fees or discounts offered by schools, IMC could include advertising (local newspaper advertisements), sales promotion (bursaries), events and experiences (sport festivals), public relations and publicity (fundraising), direct and interactive marketing (school website), personal selling (exhibitions) and word of mouth (person to person or social media). The additional marketing mix elements can be applied as follows: people could refer to educators, processes could include the enrolment process at the school and physical evidence could include aspects such as an attractive and well-maintained school building.

In response to the independent school marketing mix, independent schools need to understand their consumers and their consumption behaviour (Hoyer \& MacInnis 2010:24). The key concept of marketing is customer centrality and to realise this goal, service providers have to understand consumer decision-making: how consumers choose between different offerings and how they experience and evaluate the service offerings (Blythe 2013:3). 
The decision-making process of services consists of the pre-purchase stage, the service encounter stage and the postencounter stage (Wells \& Foxall 2012:128). The first stage of decision-making in the pre-purchase stage for prospective parents with a child in Grade 1 is the realisation of parents that the child needs to be enrolled at a school (problem recognition). According to the South African Schools Act (1996), schooling is compulsory for children aged 7 to 15 (or attendance in Grades 1 to 9, whichever comes first). The second stage of the pre-purchase stage involves investigating all possible sources of information regarding the service being offered and includes sources such as school open days and the school website. The third stage in the pre-purchase stage, namely the evaluation of alternatives, involves the act of identifying alternative solutions to a problem and assessing the relative merits and demerits of each solution (include the dimensions, features or benefits that consumers seek in making buying decisions) (Parumasur \& RobertsLombard 2012:258). The service encounter stage is the next stage in the decision-making process for services. This is the stage at which the parent has chosen an outlet (school) and paid the enrolment fee at a specific independent school. The post-encounter stage is the final stage in the decision-making process for services (Wells \& Foxall 2012:128).

Consumers evaluate service performance by comparing what they expect with what they perceive they receive from a particular supplier (Lovelock \& Wirtz 2011:74). It also happens that consumers often feel post-purchase dissonance (also referred to as cognitive dissonance), which can be described as the doubt or anxiety experienced after making a difficult and relatively permanent decision (Kotler, Armstrong \& Tait 2010:164). In the context of this study, cognitive dissonance takes place when parents doubt they had made the correct choice of an independent primary school for their child. This article focuses on the third stage in the pre-purchase stage, namely the evaluation of alternatives. In the context of this study, the evaluation of alternatives is the choice factors of parents when selecting independent primary schools. Consumers typically form a list or set of alternatives from which a choice is made; decision rules are applied to make a selection from the alternatives (Hoffman \& Bateson 2011:90).

\section{Choice factors of parents selecting independent schools}

Research into choice factors of parents selecting independent schools is limited and includes international studies by the Independent Schools Queensland Survey (ISQ 2011), the Independent Schools Council of Australia (ISCA 2008), Robinson (2008:17), Denessen, Driessena and Sleegers (2005:354), Foskett and Hemsley-Brown (2001:83) and Gorard (1999:31). The ISQ (2011) identified amongst others discipline, quality educators, the reputation of the school and academic performance as important choice factors. According to the ISCA, choice factors include the school facilities, educators, a nurturing and caring environment, small class size and discipline. Robinson identified academic standards, discipline and small classes and Denessen et al. identified academic performance, school climate and individual attention to the child as the most important choice factors cited by parents. Choice factors such as tradition, subject choices, facilities as well as the school principal are amongst the top 20 factors identified by parents (Foskett \& HemsleyBrown 2001:83). According to Gorard, the common reasons for choice of parents are academic reasons, location of the school, the management style of the school, discipline as well as security factors. As far as could be ascertained, no research exists with specific reference to choice factors that parents considered in the selection of independent primary schools in the South African context. Limited research done in the South African context on school marketing was the study by McAlister (2005:2) where the researcher aimed to understand management's attitudes towards marketing and the study by Malherbe (2004:82) where the aim was to establish whether independent schools in Gauteng have embraced a culture of marketing. The aim of a study by Vigar-Ellis (2013:10) was to understand the choice criteria of parents when enrolling their child at a secondary boarding school in South Africa.

\section{Problem statement, objectives and hypotheses}

The changing independent school landscape in South Africa, with independent schools experiencing a strong growth in the market (from 971 independent schools in 2000 to 1571 independent schools in 2012), has encouraged the development of a market culture amongst independent schools (Malherbe 2004:82). Parents can choose from a variety of independent schools, especially in Gauteng, which has the highest number of independent schools (566 or 36\% of all independent schools) in South Africa (Department of Basic Education 2012). To survive in this competitive environment, independent schools have to become more marketing orientated (McAlister 2005:2; Malherbe 2004:8). However, some independent schools in South Africa find it difficult to market themselves effectively as a result of a lack of information pertaining to the choice factors identified by parents when selecting an independent school (B.J. Fourie pers. comm., 12 January 2012). It is therefore important for independent schools to understand what parents desire and expect from the school they choose. The research question therefore is twofold: what are the (prioritised) choice factors that parents regard as important in independent school selection and to what extent can these factors be utilised in the development of marketing guidelines by independent schools? A comprehensive set of choice factors might provide a more accurate picture of the criteria parents perceive as important in independent school selection and these choice factors can be used to develop marketing guidelines for independent schools.

The following primary goal is formulated for the study: to develop marketing guidelines for independent primary schools in order to attract more learners and to position independent primary schools more optimally in the independent school market. The following secondary objectives support the study: to identify the choice factors 
influencing parents' selection of independent primary schools and to identify the most important choice factors influencing the selecting of independent primary schools.

A study by Wiese, Van Heerden and Jordaan (2010:150) investigated the choice factors students consider when selecting a higher education institution, with the focus on the differences between gender groups.

Jordaan and Wiese (2010:538) investigated the role of ethnicity in the higher education institution selection process and Cosser and Du Toit (2002:212) found that ethnic groups differ in the importance they attach to choice factors when it comes to higher education institution selection. Language is related to ethnic groups and literature suggests differences between ethnic groups and the importance of choice factors.

Thus, the following non-directional research hypotheses were formulated for the study:

- $\mathrm{H}_{1}$ : The importance parents attach to choice factors differs in respect of gender.

- $\mathrm{H}_{2}$ : The importance parents attach to choice factors differs in respect of their home language (ethnic group) group.

- $\mathrm{H}_{3}$ : The importance parents attach to choice factors differs in respect of their qualification level.

The level of education hypothesis was supported by studies by Bosetti and Pyryt (2007:98), Friedman, Bobrowski and Markow (2007:278) and Denessen et al. (2005:353).

\section{Research method and design}

A research design is a road map for conducting a marketing research project and provides details of each step in the research project (Malhotra 2012:98). Research design includes a number of components, which are elaborated on below.

\section{Classification of the research design}

Following the literature findings, the empirical investigation was exploratory and quantitative in nature. The population comprised all Grade 1 parents from the 556 independent primary schools in Gauteng.

\section{Measurement and scaling procedures}

A structured questionnaire based on literature with a noncomparative five-point Likert scale was used to gather the data. With the Likert scale, respondents indicate their attitudes by checking how strongly they agree or disagree with carefully constructed statements, ranging from very positive to very negative attitudes (Zikmund \& Babin 2007:214). The scales used in this study ranged between 'not at all important', and 'extremely important', 'strongly disagree' and 'strongly agree' and 'not useful' and 'extremely useful'.

Respondents were provided with a self-administered questionnaire or an Internet survey, both of which included self-developed items. Suitable scale items were considered reliable and validity was established. Items and constructs in the questionnaire were developed from the literature review and the exploratory research approach.

\section{Sampling design}

A non-probability sampling approach was followed and the judgment sampling technique applied. Judgment sampling choosing the sample based on a person's judgment about some appropriate characteristics required of the sample (Zikmund \& Babin 2010:424). The data were gathered over a 12-week period (September, October and November) in 2012. During this time, either the father, mother or guardian of a child in Grade 1 who matched the sampling frame was asked to participate in the survey. A total of 669 questionnaires were completed and could be used in the analysis. The questionnaire was pretested in a pilot study involving 10 respondents from different independent primary schools in Gauteng who matched the sampling frame. The internal consistency reliability test was used to measure reliability. Validity was ensured by having the content of the questionnaire align with the research aim and objectives.

\section{Data analysis}

Data analysis included a combination of descriptive statistics to determine the relative importance of different choice factors. The statistical test used for the hypothesis was multivariate analysis of variance (MANOVA). The Pillai's trace was the test statistic used to assess the overall significance of the MANOVA (Pallant 2007:286). Because the MANOVA shows only an overall significant difference and does not indicate where a significant trace result is found, it was followed by a univariate analysis with the application of the Scheffe post-tests. These tests were performed to reveal more specific differences between groups on each of the identified choice factors. The significance level for this study was set at a $95 \%$ confidence level, thus $\alpha=0.05$. The data obtained from the questionnaires was coded, captured and edited. The Statistical Package for Social Sciences (SPSS version 18) was used to analyse the results. The data obtained from the field were coded and captured in the statistical software package. Cronbach's alpha coefficients were calculated to determine whether the results for each scale used in the questionnaire (i.e. the choice construct and its different factors) were reliable.

\section{Results}

Statistical techniques were applied and produced the following results.

\section{Reliability}

Cronbach's alpha was used as a measure of the internal consistency reliability for the measurement of the importance of the attributes. Cronbach's alpha values above 0.7 are deemed to have a good strength of association and 
TABLE 1: Cronbach's alpha coefficients for constructs.

\begin{tabular}{lc}
\hline Constructs & Cronbach's alpha \\
\hline Academic factors & 0.841 \\
Organisational factors & 0.742 \\
Sport and cultural factors & 0.848 \\
Situational factors & 0.659 \\
School characteristics & 0.606 \\
School leadership & 0.770 \\
School appearance & 0.643 \\
Class size & 0.681 \\
\hline
\end{tabular}

TABLE 2: Kaiser-Meyer-Olkin and Bartlett's test of sphericity.

\begin{tabular}{lcc}
\hline Test & $\begin{array}{c}\text { Value of forced exploratory } \\
\text { factor analysis }\end{array}$ \\
\hline Kaiser-Meyer-Olkin measure of sampling adequacy & 0.856 \\
$\begin{array}{ll}\text { Bartlett's test of } \\
\text { sphericity }\end{array}$ & Approximate chi-square & 5652.193 \\
& DF & 406 \\
& Significance & 0.000 \\
\hline
\end{tabular}

are acceptable (Hair et al. 2007). According to Hair et al. (2010:708), when calculating Cronbach's alpha, results just exceeding 0.60 will reflect lower levels of acceptability. The reliability statistics for the questionnaire are presented in Table 1.

It is evident from Table 1 that the Cronbach's alpha coefficients for all eight constructs investigated are above the lower limit of acceptability, 0.60. This confirms that the collected data that were used were internally consistent (reliable).

\section{Validity}

Validity can be attained by aligning the content of the questionnaire with the research objectives (Van Tonder \& Ehlers 2011:164). Consequently, the following activities were performed to ensure validity and reliability: a selfadministrated questionnaire was designed, which was directly aligned with the research aim and objectives. The necessary adjustments were made to the questionnaire, based on feedback obtained from the pilot study. A sufficiently large sample size was used to increase the accuracy of the results.

The expertise of STATKON (the Statistical Consultation Services) of the University of Johannesburg was employed to analyse the data gathered and to ensure the correct measurements of the results.

Factor analysis was used to assess the structural validity of the choice factors construct and exploratory factor analysis was used in an attempt to gain insight into the structural validity. The 29 items of the choice factor scale were according to Pallant (2007:181) subjected to principal component analysis (PCA); prior to performing PCA, the suitability of data for factor analysis was assessed using the Kaiser-Meyer-Olkin (KMO) test for sampling adequacy and Bartlett's test of sphericity results. This is presented in Table 2 .
TABLE 3: Demographic profile of respondents.

\begin{tabular}{lcc}
\hline Variable & \multicolumn{2}{c}{ Overall } \\
\cline { 2 - 3 } & & N \\
\hline Gender & 515 & 77.0 \\
Female & 154 & 23.0 \\
Male & 669 & 100 \\
\hline Total & & \\
Home language & 236 & 35.3 \\
Afrikaans & 286 & 42.7 \\
English & 44 & 6.6 \\
Nguni (IsiZulu, IsiXhosa, IsiSwati, IsiNdebele) & 75 & 11.2 \\
Sotho (SeSotho s Leboa, Sesotho, Setswana) & 10 & 1.5 \\
Venda & 18 & 2.7 \\
Other & 669 & 100 \\
\hline Total & & \\
\hline Highest academic qualification & 266 & 39.8 \\
Postgraduate degree & 105 & 15.7 \\
Undergraduate degree & 192 & 28.7 \\
Higher diploma or diploma & 100 & 14.9 \\
Grade 12 (Matric) & 3 & 0.4 \\
Missing & 669 & 100 \\
\hline Total & &
\end{tabular}

It is evident from Table 2 that the 29 statements are suitable for factor analysis: KMO of 0.856 , which is greater than 0.6 and Bartlett's test of sphericity is 0.000 , which is smaller than 0.05 (Pallant 2010:187).

\section{Demographic profile of respondents}

Of the total 669 respondents from 30 independent schools in Gauteng, of South Africa, who participated in the study, $77 \%$ were female, $43 \%$ had English as their home language, followed by $35 \%$ Afrikaans and $11 \%$ Sotho. Almost $40 \%$ of the respondents had a postgraduate degree, followed by $15 \%$ with an undergraduate degree. The demographic profile of the respondents is presented in Table 3.

\section{Choice factors influencing the selection of independent primary schools}

Concerning the first research objective, respondents identified 29 variables that they considered when making a decision regarding the independent primary school at which they chose to enrol their child. These variables are categorised into eight factors and are presented in Table 4.

From Table 4, the main finding is that all eight choice factors realised an overall mean score above 3 , indicating that all eight factors play an important role in influencing parents' independent school choice. Five of the eight factors realised an overall mean of above 4 (class size, organisational factors, school characteristics, school leadership and academic factors), indicating that these five factors play a very important role in influencing parents' selection of an independent school.

Class size (small class size and individual attention to the child) was cited as the most important choice factor by parents when selecting an independent primary school. 
TABLE 4: Choice factors identified.

\begin{tabular}{|c|c|c|}
\hline Factor & Factor loading & Statement \\
\hline \multirow[t]{4}{*}{$\begin{array}{l}\text { Academic factors } \\
(\text { Mean }=4.06)\end{array}$} & 0.797 & $\begin{array}{l}\text { Benchmarked academic } \\
\text { curriculum standards. }\end{array}$ \\
\hline & 0.757 & $\begin{array}{l}\text { Assessment body of the } \\
\text { national senior certificate. }\end{array}$ \\
\hline & 0.733 & $\begin{array}{l}\text { Academic performance (pass } \\
\text { rate and exemption rate). }\end{array}$ \\
\hline & 0.631 & $\begin{array}{l}\text { Range of subject choices } \\
\text { preparing for high school. }\end{array}$ \\
\hline \multirow[t]{5}{*}{$\begin{array}{l}\text { Organisational factors } \\
(\text { Mean }=4.54)\end{array}$} & 0.613 & $\begin{array}{l}\text { Atmosphere exhibited in the } \\
\text { classroom. }\end{array}$ \\
\hline & 0.606 & $\begin{array}{l}\text { Safe environment for } \\
\text { learners. }\end{array}$ \\
\hline & 0.558 & $\begin{array}{l}\text { Qualified and committed } \\
\text { educators. }\end{array}$ \\
\hline & 0.508 & Academic facilities. \\
\hline & 0.485 & Overall image of the school. \\
\hline \multirow[t]{3}{*}{$\begin{array}{l}\text { Sport and cultural } \\
\text { factors (Mean }=3.81 \text { ) }\end{array}$} & 0.884 & $\begin{array}{l}\text { Variety of sport for } \\
\text { participation. }\end{array}$ \\
\hline & 0.713 & Sport facilities. \\
\hline & 0.701 & $\begin{array}{l}\text { Variety of co-curricular } \\
\text { activities. }\end{array}$ \\
\hline \multirow[t]{5}{*}{$\begin{array}{l}\text { Situational factors } \\
\text { (Mean }=3.47 \text { ) }\end{array}$} & 0.700 & $\begin{array}{l}\text { Provision of transport to the } \\
\text { school. }\end{array}$ \\
\hline & 0.622 & Aftercare facilities. \\
\hline & 0.559 & Multicultural school. \\
\hline & 0.371 & Affordable school fees. \\
\hline & 0.320 & Location of the school. \\
\hline \multirow{5}{*}{$\begin{array}{l}\text { School characteristics } \\
(\text { Mean }=4.29)\end{array}$} & 0.536 & Positive discipline. \\
\hline & 0.494 & $\begin{array}{l}\text { School with established } \\
\text { traditions. }\end{array}$ \\
\hline & 0.400 & Religious ethos of the school. \\
\hline & 0.382 & Positive word-of-mouth. \\
\hline & 0.373 & Language of instruction. \\
\hline \multirow[t]{2}{*}{$\begin{array}{l}\text { School leadership } \\
\text { (Mean }=4.28 \text { ) }\end{array}$} & 0.786 & $\begin{array}{l}\text { Reputation of the school } \\
\text { principal. }\end{array}$ \\
\hline & 0.522 & $\begin{array}{l}\text { Leadership of the school } \\
\text { owners or board of directors. }\end{array}$ \\
\hline \multirow{2}{*}{$\begin{array}{l}\text { School appearance } \\
(\text { Mean }=3.51)\end{array}$} & 0.731 & Attractive school building. \\
\hline & 0.497 & School uniform. \\
\hline \multirow[t]{2}{*}{$\begin{array}{l}\text { Class size } \\
(\text { Mean }=4.70)\end{array}$} & 0.653 & $\begin{array}{l}\text { Individual attention to the } \\
\text { child. }\end{array}$ \\
\hline & 0.607 & Small class size. \\
\hline
\end{tabular}

The hypotheses focus specifically on reporting on significant differences between demographic groups with regard to the main constructs of the research, namely the factors influencing independent school choice:

- $\mathrm{H}_{1(0)}$ : The importance parents attach to choice factors does not differ in respect of gender.

- $\mathrm{H}_{1}$ : The importance parents attach to choice factors differs in respect of gender.

A one-way between-groups MANOVA was performed to investigate gender differences of respondents in terms of the importance they attach to choice factors. There was a statistically significant difference between male and female respondents on the combined dependent variables $(F[8.658]=3.9, p=0.000$; Pillai's trace $=0.045$; partial eta squared $=0.045$ ). Although a statistically significant result was obtained, the effect size was small (eta squared $=0.045$ ).

The null hypothesis $\left(\mathrm{H}_{1(0)}\right)$ was thus rejected, as there is support for $\mathrm{H}_{1}$.
Female parents (i.e. mothers) agree significantly more than male parents (i.e. fathers) in terms of the importance that they attach to different choice factors in their independent school choice. These differences are present for seven of the eight choice factors, namely academic factors, organisational factors, sport and cultural factors, school characteristics, school leadership, school appearance and class size, and were found to be statistically significantly different by gender:

- $\mathrm{H}_{2(0)}$ : The importance parents attach to choice factors does not differ in respect of home language.

- $\mathrm{H}_{2}$ : The importance parents attach to choice factors differs in respect of home language.

The above-mentioned hypothesis involves the comparison between three groups, namely Afrikaans, English and other African languages, on a set of choice factors. A one-way between-groups MANOVA was performed to investigate home language differences of respondents regarding the importance they attach to choice factors.

There was a statistically significant difference between home languages of respondents on the combined dependent variables $(F[16,1280]=11.4, p=0.000$; Pillai's trace $=$ 0.25 ; partial eta squared $=0.12$ ). Although a statistically significant result was obtained, the effect size was medium (eta squared $=0.12$ ).

The null hypothesis $\left(\mathrm{H}_{2(0)}\right)$ was thus rejected, as there is support for $\mathrm{H}_{2}$

Parents with different home languages differ in the importance they attach to different choice factors in their independent school choice. These differences are present for four of the eight choice factors, namely organisational factors, sport and cultural factors, situational factors and school appearance. Parents with English as their home language rated the importance of organisational factors and sport and cultural factors higher than parents with Afrikaans and other languages as their home language. Parents with other languages as their home language rated the importance of situational factors and school appearance higher than parents with Afrikaans and English as their home language:

- $\mathrm{H}_{3(0)}$ : The importance parents attach to choice factors does not differ in respect of their qualification level.

- $\mathrm{H}_{3}$ : The importance parents attach to choice factors differs in respect of their qualification level.

The above-mentioned hypothesis involves the comparison between four groups, namely respondents with matric, diploma or higher diploma, undergraduate degree or postgraduate degree, on a set of choice factors. There was a statistically significant difference between the qualification levels of respondents on the combined dependent variables $(F[24.1956]=1.70, p=0.018$; Pillai's trace $=0.06$; partial eta squared $=0.02$ ). Although a statistically significant result was obtained, the effect size was small (eta squared $=0.02$ ). 
TABLE 5: Top five choice factors identified.

\begin{tabular}{lll}
\hline Rank number & Choice factor & Mean \\
\hline 1 & Small class size & 1.84 \\
2 & Religious ethos & 1.38 \\
3 & Qualified and committed educators & 1.26 \\
4 & Positive discipline & 1.12 \\
5 & Individual attention to the child & 1.03 \\
\hline
\end{tabular}

The null hypothesis $\left(\mathrm{H}_{3(0)}\right)$ was thus rejected, as there is support for $\mathrm{H}_{3}$.

Parents with different academic qualification levels differ in the importance they attach to different choice factors in their independent school choice. These differences are present for two of the eight choice factors, namely situational factors and school appearance. Parents with a matric or undergraduate or diploma qualification rated the importance of situational factors and school appearance higher than parents with a postgraduate qualification.

\section{The most important choice factors influencing the selection of independent primary schools}

Concerning the second research objective, respondents were asked to rank the top five individual choice factors (from the set of 29 variables). These results are presented in Table 5.

From Table 5 it is clear that the rank total difference between the first rank choice factor (small class size) and the other choice factors (second to fifth) is statistically significant.

\section{Managerial implications}

The findings of the conducted survey indicate a number of managerial implications for independent primary schools. The primary aim of this article was to recommend marketing guidelines for independent primary schools and provide an understanding of how these choice factors can assist independent schools in South Africa to market themselves better to parents when the latter are selecting an independent school for their children, in order to position independent primary schools more optimally in the market. To accomplish this objective involves the coordination and combination of the marketing mix elements that enable independent schools to meet parents' needs. These marketing mix elements include product, price, promotion (also referred to as IMC), process, physical evidence and people. For the purposes of this article, only recommendations with regard to product and people are applicable, because only the choice factors applicable to these marketing mix elements and the importance thereof were determined.

\section{Product}

In light of the findings, it is clear that independent schools should focus on small classes (maximum 20 learners) as this was the most important choice factor that parents cited when selecting independent primary schools. This finding corresponds with the study by Foskett and HemsleyBrown (2001:83) where small class size was the most important choice factor. Small class size was also one of the top choice factors cited by Australian parents in the ISCA (2008) survey. The study by Robinson (2008:17) indicated that small class size was the second ranked choice factor. Individual attention to the child is the fifth ranked choice factor by parents when selecting independent primary schools in Gauteng, which corresponds with the ISQ (2011) survey. A study by Denessen et al. (2005:354) as well as one by Foskett and Hemsley-Brown (2001:83) ranked individual attention as the third most important choice factor.

In terms of class size, it is recommended that small class size with individual attention to the child needs to be promoted as a competitive edge in choosing an independent school. This choice factor must be highlighted at school open days, on the school website, at school expos or in any other marketing material distributed by the school.

The maximum number in a class needs to be respected at all times and it is recommended that independent schools not only promote the small class size, but also promote the academic and other benefits of small classes (Parker, Cook \& Pettijohn 2007:22). The benefits include that small class sizes allow educators to gain knowledge of their learners and their unique strengths and individual needs. The smaller class size encourages learners' active participation and allows educators a unique opportunity to monitor every learner's progress. Learners can grow and flourish according to their interests and abilities. Individual attention to the child is related to small classes, which is the top choice factor when parents select an independent school. When a class is small and individual attention is given to the child, better discipline in the class will be maintained. Individual attention to a child also implies that each child in the class can obtain an improved understanding of the concepts explained in the class and any problems can be picked up immediately by the educator in the class and can be rectified.

The religious ethos of the independent school was confirmed as the second most important choice factor, a finding that does not correspond with other international studies (Foskett \& Hemsley-Brown 2001:83; ISCA 2008; ISQ 2011; Robinson 2008:17). Marketing guidelines recommended are that the school needs to have a strong commitment to moral values and character development. Parents must have the choice to enrol their child at an independent school that is a relatively close match to their belief systems. Due to the high ranking of religious ethos as choice factor, it is recommended that this choice factor must be highlighted in all information sources that the school employs, which may include advertising (e.g. local newspapers and street pole advertising), events 
and experiences, public relations and publicity, direct and interactive marketing, as well as social media.

Positive discipline at the independent school was confirmed as the number four choice factor. A marketing guideline that is recommended is that the independent school implement a school discipline procedure and anti-bullying policy to establish positive discipline at the school. The discipline policy and procedure need to be promoted by the school as a measure to mentor and encourage behaviour that is acceptable. The discipline procedure can be published on the school's website or communicated at parent evenings. In addition, the independent school needs to promote that learners with discipline problems should not be humiliated or shamed by the educator and that the school endeavours to work with the parents to develop and help such a learner. It is recommended that independent schools reward good behaviour, as it is believed that this will develop an ethos of kindness and cooperation. Positive behaviour at a primary school may include an encouraging word or a positive written comment in the book of learners, a school letter sent home stating the positives, a certificate issued at a special assembly or a visit to the principal where they will be recognised for exceptional work.

\section{People}

Qualified and committed educators at independent schools were confirmed as the number three choice factor. This corresponds with the studies by ISCA (2008), ISQ (2011) as well as Robinson (2008:17), which identified qualified and committed educators as one of the top three choice factors. A marketing guideline recommended is that independent primary schools recruit, retain and reward the best educators.

In some independent schools the salaries of educators are less than in government schools; this needs to be addressed by the school owners or board of directors in an effort to retain the best educators. It is also recommended that the management of independent schools acknowledge the achievements of educators on a regular basis. This acknowledgement can be on the school's website and on social media. It is also recommended that the school publish the names and contact details of educators on the school's website in order for parents to get to know the educators and for prospective parents to make an informed decision when selecting the independent school. Independent schools may also establish a culture of support, training and learning for educators so that all educators can improve their skills and develop their unique qualities.

\section{Limitations of the study and future research}

The study focused on 30 independent primary schools in Gauteng, South Africa, representing 669 parents of children enrolled in Grade 1. The study therefore cannot be seen as representative of the entire industry in the province or the country. As the study only focused on Gauteng and only independent primary schools, a more inclusive study of all provinces in South Africa (including high schools) is therefore recommended. A comparative study with public schools in South Africa (not included in the study) can also be considered.

\section{Conclusion}

Parents in South Africa can enrol their child at any school in the country: parents are not forced to enrol their child at the nearest school, but have a choice to enrol learners at the school of their preference (Van Wyk \& Bisschoff 2012:431). The growth in the independent school industry is driven by a growing middle class in South Africa wanting highquality education for their children (Hasenfuss 2011). Due to the competitiveness of independent schools, a better understanding of a comprehensive set of choice factors that influence independent school preference amongst prospective parents will assist these schools to better their marketing efforts in order to attract new learners and to more optimally position themselves in the independent school market. It is therefore important that the schools' marketing strategy emphasises those choice factors.

The findings of the study revealed that small class size is the most important choice factor of parents when selecting independent primary schools, followed by the religious ethos of the school and qualified and committed educators. This implies that independent schools can improve their marketing efforts by especially ensuring that classes are small and provide individual attention to the child. The religious ethos of the school is also of utmost importance because parents prefer to enrol their child at an independent school that is a relatively close match to their belief systems. Another marketing guideline for independent schools is to recruit, retain and reward the best educators for their schools.

Independent schools should implement a school discipline procedure and anti-bullying policy to establish positive discipline at the school. However, further research needs to be conducted to examine the choice factors of parents in both primary and secondary schools. A similar study can also be conducted to determine the choice factors of parents when selecting an independent school versus a public school.

\section{Acknowledgements Competing interests}

The authors declare that they have no financial or personal relationship(s) which may have inappropriately influenced them in writing this article.

\section{Authors' contributions}

Both authors (University of Johannesburg) contributed to the writing and research of this article.

\section{References}

Bisschoff, T., Du Plessis, P. \& Smith, E., 2004, Effective school marketing, Van Schaik, Cape Town.

Blythe, J., 2013, Consumer behaviour, 2nd edn., South-Western, London. 
Bosetti, L. \& Pyryt, M.C., 2007, 'Parental motivation in school choice: Seeking the competitive edge', Journal of School Choice 1(4), 89-108, http://dx.doi. the competitive edge', Journal of
org/10.1300/15582150802098795

Boshoff, C. \& Du Plessis, F., 2009, Services marketing - A contemporary approach, Juta \& Company Ltd, Cape Town.

Cant, M.C. \& Van Heerden, C.H., 2010, Marketing management: A South African perspective, Juta \& Co. Ltd, Cape Town

Cosser, M. \& Du Toit, J., 2002, From school to higher education? Factors affecting the choices of grade 12 learners, HSRC Publishers, Cape Town.

Denessen, E., Driessena, G. \& Sleegers, P., 2005, 'Segregation by choice? A study of group-specific reasons for school choice', Journal of Education Policy 20(3), 347-368. http://dx.doi.org/10.1080/02680930500108981

Department of Basic Education, 2012, School realities, viewed 11 September 2012 from http://www.education.gov.za/DocumentsLibrary/Publications

Federation of Governing Bodies of South African Schools (Fedsas), 2013, Legislation The South African Schools Act, No. 84 of 1996, viewed 19 October 2013, from http:///www.fedsas.org.za/english/downloads

Foskett, N.H. \& Hemsley-Brown, J., 2001, Choosing futures: Young people's decision making in career, education and training markets, Routledge Flamer, London. http://dx.doi.org/10.4324/9780203467534

Friedman, B.A., Bobrowski, P.E. \& Markow, D., 2007, 'Predictors of parents' satisfaction with their children's school', Journal of Educational Administration 45(3), 278-288. http://dx.doi.org/10.1108/09578230710747811

Gorard, S., 1999, 'Well, that about wraps it up for school choice research: A state of the art review', Journal of School Leadership and Management 19(1), 25-47. http://dx.doi.org/10.1080/13632439969320

Hair, J.F., Money, A.H., Samouel, P. \& Page, M., 2007, Research methods for business, John Wily and Sons, England.

Hair, J.F., Wolfinbarger, M.F., Ortinau, D.J. \& Bush, R.F., 2010, Essentials of marketing research, 2nd edn., McGraw-Hill, New York, NY.

Hasenfuss, M., 2011, 'School fees paid: Will PSG make money out of private education?', Fin Week 14, 28 April.

Hawkins, D.I., Mothersbough, D.L. \& Mookerjee, A., 2010, Consumer behaviour Building marketing strategy, 11 th edn., Tata McGraw-Hill, New Delhi.

Hoffman, K.D. \& Bateson, J.E.G., 2011, Services marketing: Concepts, strategies and cases, 4th edn., Thomson South-Western, Mason, $\mathrm{OH}$.

Hoyer, W.D. \& MacInnis, D.J., 2010, Consumer behaviour, 2nd edn., Houghton Mifflin Boston, IL.

Independent Schools Association of Southern Africa (ISASA), 2013, Marketers ISMA viewed 02 January 2013, from http://www.isasa.org

Independent Schools Council of Australia (ISCA), 2008, Factors affecting school choice, viewed 31 October 2012, from http://www.isca.edu.au

Independent Schools Queensland Survey, 2011, What parents want, viewed 23 May 2011, from http://www.aisq.qld.edu.au/files/Communications/survey/what Parnets_Want_SurveyReport-2011.pdf

International Finance Corporation (IFC), 2010, Education investment guide, viewed 15 June 2013, from http://www.ifc.org/wps/connect

Jordaan, Y. \& Wiese, M., 2010, 'The role of ethnicity in the higher education institution selection process', South African Journal of Higher Education 24(4), 538-554.

Kotler, P., Armstrong, G. \& Tait M., 2010, Principles of marketing: Global and Southern African perspectives, Pearson, Cape Town.

Losike-Sedimo, N.C., 2011, 'Factors influencing parents' choice of school for their children in Botswana: Marketing strategy for customer loyalty', Far East Journal of Psychology and Business 3(1), 32-40.
Lovelock, C. \& Wirtz, J., 2011, Services marketing: People, technology and strategy, 7th edn., Pearson, New Jersey.

Malherbe, P.J., 2004, 'The marketing of independent schools in Gauteng', MCom dissertation, Rand Afrikaans University, Johannesburg.

Malhotra, N.K., 2012, Basic marketing research, integration of social media, 4th edn., Pearson Education International, New Jersey.

McAlister, D.R., 2005, 'A marketing strategy for independent schools', Med dissertation, University of Johannesburg.

McGovern, M., 2012, 'What motivates parents', Independent School Magazine 71(6) $16-21$.

Molland, J., 2007, Straight talk about schools today: Understand the system and help your child succeed, Free Spirit, Minneapolis, MN.

Oplatka, I., 2007, 'The principal's role in marketing the school: Subjective interpretations and personal influences', Planning and Changing 38(3), 208-221.

Oplatka, I. \& Hemsley-Brown, J., 2004, 'The research on school marketing: Current issues and future directions', Journal of Educational Administration 42(3), 375397. http://dx.doi.org/10.1108/09578230410534685

Pallant, J., 2007, SPSS survival manual, 3rd edn., McGraw-Hill Education, England.

Pallant, J., 2010, SPSS survival manual, 4th edn., McGraw-Hill Education, England.

Parker, R.S., Cook, S. \& Pettijohn, C.E., 2007, 'School choice attributes: Positioning a private school', Services Marketing Quarterly 28(4), 21-33. http://dx.dol. org/10.1300/J396v28n04_02

Parumasur, S.B. \& Roberts-Lombard, M., 2012, Consumer behaviour, 2nd edn., Juta, Cape Town.

Petruzzellis, L. \& Romanazzi, S., 2010, 'Educational value: How students choose university, Evidence from an Italian university', International Journal of Educationa Management 24(2), 139-158. http://dx.doi.org/10.1108/09513541011020954

Robinson, J., 2008, Public attitudes to independent schools, viewed 07 July 2011, from http://www.ipsos-mori.com/Assets/Docs/Publications/

Roodt, M., 2011, Independent schooling growing apace in South Africa, viewed 29 January 2011, from http://www.sairr.org.za/media/media-releases

Sferle, S., Gârdan, D.A., Gudei, S.C. \& Geangu, I.P., 2012, 'Implementation of marketing principles - A necessity in primary school education', Contemporary Reading in Law and Social Justice 4(2), 764-773.

Soedijati, E.K. \& Pratminingsih, S.A., 2011, 'The impacts of marketing mix on students' choice of university', in Conference proceedings of the 2nd International Conference on Business and Economic Research, Universitas Widyatama, Indonesia.

Van Tonder, E. \& Ehlers, L., 2011, 'Factors threatening the survival of independent financial advisers in their organisational life cycle: An exploratory study', South African Journal of Economic and Management Sciences 14(2), 155-169.

Van Wyk, A. \& Bisschoff, C., 2012, " $n$ Meetinstrument om die beeld van ' $n$ sekondêre skool te bepaal [A measuring instrument to determine the image of a secondary school]', Tydskrif vir Geesteswetenskappe 52(3), 415-432.

Vigar-Ellis, D., 2013, 'Boys' boarding school management: Understanding the choice criteria of parents', South African Journal of Education 33(1), 1-15.

Wells, V. \& Foxall, G.R., 2012, Handbook of developments in consumer behaviour' Elgar Publishing Limited, Cheltenham. http://dx.doi.org/10.4337/9781781005125

Wiese, M., Van Heerden, C.H. \& Jordaan, Y. 2010, The role of demographics in students' selection of higher education, Acta Commercii 10(1), 150-163.

Zikmund, W.G. \& Babin, B.J., 2007, Exploring marketing research, 9th edn., Thomson South-Western, Mason, $\mathrm{OH}$

Zikmund, W.G. \& Babin, B.J., 2010, Exploring marketing research, 10th edn., intl edn., South-Western, Cengage Learning, Stamford, CT. 